\title{
CURRENT RULES OF THE DEPOSIT GUARANTEE SYSTEM IN POLAND
}

\author{
PATRYCJA ZAWADZKA*
}

\section{INTRODUCTION}

The Deposit Guarantee Scheme (DGS) provide a safety mechanism for depositors in order that, if a credit institution fails, they will be able to recover at least a part of their bank deposits. The most important of EU regulations in this area is Directive 94/19/EC of the European Parliament and Council of 30 May 1994 on deposit-guarantee schemes, ${ }^{1}$ which was adopted in 1994 for implementation by 1 July 1995 and amended by Directive 2009/14/EC of the European Parliament and Council of 11 March 2009 , with the amendment relating to coverage level and payout delay. ${ }^{2}$ A number of the provisions in the amending directive were to be implemented by 30 June 2009, but certain of them by 31 December 2010. In the past three years Polish legislators have undertaken a number of significant regulatory reforms to implement Directive 2009/14/EC in response to the financial crisis. The aim of this article is to illustrate the actual form of the deposit guarantee system in Poland and to answer the question of whether the legal provisions of the Act on the Bank Guarantee Fund of 14 December $1994^{3}$ are in full compliance with Directives 94/19/EC and 2009/14/EC.

\section{ORIGINS, TASKS AND ORGANIZATION OF THE BANK GUARANTEE FUND}

The Bank Guarantee Fund (the BFG, the "Fund"), an institution managing the deposit guarantee scheme in Poland, was created by the Act on the BFG in 1994 which has been in force since 17 February 1995. The

DOI: $10.2478 /$ wrlae-2013-0041

* PhD; LLM; Department of Financial Law, University of Wroclaw.

p.zawadzka@prawo.uni.wroc.pl

1 European Parliament and Council Directive 94/19/EC of 30 May 1994 on depositguarantee schemes [1994] OJ L135/5.

2 European Parliament and Council Directive 2009/14/EC of 11 March 2009 amending Directive 94/19/EC on deposit-guarantee schemes as regards coverage level and payout delay [2009] OJ L68/3.

${ }^{3}$ Journal of Laws 2009 No. 84, item 711 (as amended) (The Act on the BFG). 
Fund is an independent legal person with its office in Warsaw and was established to maintain stability in the Polish banking system. The supervision of its operation is carried out by the Minister of Finance (as the minister competent for financial institutions) on the basis of the criteria of legality and compliance with the statute. Organs of the Fund include the Fund Council ${ }^{4}$ and Fund Management Board. ${ }^{5}$ The Fund Council and Fund Management Board perform their functions with the assistance of the Office of the Fund. ${ }^{6}$ The Bank Guarantee Fund works closely with the Polish financial security network institutions on a regular basis. These include the Finance Ministry, the National Bank of Poland and the Financial Supervision Authority.

The operations of the BFG focus on guaranteeing, aiding, controlling and analysing. It is intended that the Fund reimburse, in the event of the bankruptcy of a bank which is a participant in the guarantee scheme, funds accumulated in a bank up to the amount specified by the Act on the BFG, This is the so-called 'pay-box function'. ${ }^{7}$ The second basic task of the Fund is to make available financial assistance to banks which have found themselves faced with a loss of solvency and are engaging in independent reforms, and also to support processes concerning the merger of endangered banks with strong banks. This is known as the 'risk-minimizer' function in that the BFG may play an important role in crisis management by providing additional liquidity to a credit institution, mitigating the risk of instability of the banking sector. In the case of the controlling and analyzing function, the BFG collects and analyzes informations about entities covered by the guarantee system, paying particular attention to the identification of any risk of deterioration in their financial standing. The role of the Fund is to anticipate the condition of the banking sector with regard to threats to the stability of these banks. Some of the basic tasks of the BFG are gathering and analyzing information about banks participating in the deposit guarantee scheme. Implemented in this area - in association with the NBP - was a new reporting system for banks.

\footnotetext{
4 The Fund Council consists of the chairperson and seven members appointed and dismissed by: the Minister of Finance - two members; the President of the National Bank of Poland (NBP) - two members; the Chairperson of the Polish Financial Supervision Authority (PFSA) - one member; the Association of Polish Banks - two members (art 6(3) of the Act on the BFG). The Chairperson of the Fund Council is appointed and recalled by the Minister of Finance, having consulted the President of the NBP and the Chairperson of the PFSA.

${ }^{5}$ The Fund Management Board consists of three to five members, including the president and vice-president. The president and vice-president are elected by the Fund Council from among the members of the Fund Management Board (art 9(5) of the Act on the BFG).

${ }^{6}$ The Office of the Fund consists of seven departments (Treasury and Analysis Department, IT and Administration Department, Deposit Guarantee Department, Financial Assistance Department, Legal Department, Accounting and Financial Department, Control and Monitoring Department) and the President's Cabinet, Internal Audit Position and Operational Risk Position.

7 Adam Pawlikowski, 'Polski system gwarantowania depozytów na tle rozwiązań zastosowanych w innych państwach UE' (2005) 193 Materiały i Studia 23.
} 
Table 1. The 'pay-box' and 'risk-minimizer' functions of the Polish deposit guarantee system.

\begin{tabular}{|c|c|c|}
\hline $\begin{array}{l}\text { Function of the deposit } \\
\text { guarantee system }\end{array}$ & $\begin{array}{l}\text { Source of financing for the } \\
\text { activity }\end{array}$ & Allocation of resources \\
\hline $\begin{array}{l}\text { 'Pay-box' function } \\
\text { (guarantee activity) }\end{array}$ & $\begin{array}{l}\text { - the Guarantee Assets } \\
\text { Protection Fund (the } \\
\text { resources collected by banks) } \\
\text { - amounts obtained by the } \\
\text { Fund from bank bankruptcy } \\
\text { estates } \\
\text { - resources from the } \\
\text { assistance fund } \\
\text { - other BFG funds }\end{array}$ & $\begin{array}{l}\text { disbursement of guarantee } \\
\text { sums to depositors in the } \\
\text { event of the bankruptcy of a } \\
\text { bank which is a participant in } \\
\text { the guarantee scheme }\end{array}$ \\
\hline \multirow[t]{2}{*}{$\begin{array}{l}\text { 'Risk-minimizer' } \\
\text { function (assistance } \\
\text { activity) }\end{array}$} & $\begin{array}{l}\text { the Assistance Fund } \\
\text { (from mandatory } \\
\text { annual fees remitted by all } \\
\text { participants of the guarantee } \\
\text { scheme and Fund balance } \\
\text { sheet surplus distributions) }\end{array}$ & $\begin{array}{l}\text { - assistance to commercial } \\
\text { banks (self-recovery, bank } \\
\text { acquisitions, share purchase) } \\
\text { - assistance to cooperative } \\
\text { banks (self-recovery, merger } \\
\text { processes) }\end{array}$ \\
\hline & $\begin{array}{l}\text { the Cooperative } \\
\text { Bank Restructuring Fund }\end{array}$ & $\begin{array}{l}\text { assistance to cooperative } \\
\text { banks: } \\
\text { - unification of banking } \\
\text { technology, IT, finance and } \\
\text { accounting procedures, } \\
\text { banking products and services } \\
\text { offered } \\
\text { - purchase of shares in the } \\
\text { acquiring bank }\end{array}$ \\
\hline
\end{tabular}

Source: Own table, according to the Bank Guarantee Fund, ‘Annual Report 2009' [2010]

<http://www.bfg.pl/doc_media/wezel_799/rr_2009_en.pdf > accessed 30 May 2011.

The sources of financing for the operation of the Fund include mainly the guaranteed assets protection fund (used for aid operation), annual contributions payable by entities covered by the guarantee system (used mostly for financing aid operation) and income from interest on loans granted by the Fund, as well as interest on securities, ${ }^{8}$ in which the Fund can invest its resources.

Directive 94/19/EC obliges member states of the EU to ensure the existence of one or more deposit guarantee systems on their territory, so as to protect depositors. According to the Act on the BFG, there are two possible guarantee schemes: obligatory and contractual. ${ }^{9}$ The purpose of the

\footnotetext{
${ }^{8}$ Funds obtained by entities covered by the guarantee system under loans, guarantees or endorsements granted by the Fund may be allocated exclusively for elimination of insolvency risk or acquisition of bank shares or stocks by new shareholders or stockholders (art 19(2) of the Act on the BFG). In practice they are located mostly in money bills, treasury bonds and bills.

${ }^{9}$ Entities covered by the guarantee system which fulfill the obligations imposed on them in accordance with the provisions of the Act on the BFG may extend the funds guarantee
} 
obligatory guarantee system is to ensure disbursement to depositors of guaranteed funds, up to the amount of EUR 100,000, in the event of their unavailability (art 21 and 23(1) of the Act on the BFG).

The Act on the BFG set down a requirement that all domestic banks (having a registered office in the Republic of Poland) and branches of foreign banks (having a registered office outside the Republic of Poland, in a country not a Member State of the European Union), declared that they do not participate in the funds guarantee system or the guarantee system they participate in fails to ensure guarantees for funds at least with the scope and in the amount stipulated in the Act on the BFG. A branch of a foreign bank is covered by the guarantee system inasmuch as the guarantee system in the country of its registered seat fails to ensure disbursement of guaranteed funds within the limits stipulated in the Act on the BFG. A branch of a credit institution which conducts business in Poland may join the obligatory guarantee system in Poland for supplementary cover if the deposit guarantee scheme of the home country is not equivalent to the Polish scheme in the amount stipulated in the Act on the BFG. ${ }^{10}$ The central feature of participation is the regular payment by credit institutions of annual contributions, which are pooled and managed by the BFG so as to secure the funds required for the fulfillment of its mandate.

Art 2(1) of the Act on the BFG defines a 'depositor' as a natural person, a legal person, as well as an organizational unit without legal personality, provided it has legal capacity, and a school savings association and employee loan and relief program stipulated in art 49(3) of the Banking Act of 29 August 1997, ${ }^{11}$ being a party to a bank account agreement held in the name of the account holder or having a claim resulting from banking activities towards the bank covered by the obligatory guarantee system; persons who have a claim resulting from a sum spent on the funeral expenses of an account holder in the event of the death of a holder of a savings account, personal account or time deposit savings account and institutions disbursing insurance or social security benefits or other retirement benefits (stipulated in art 55(1) of the Banking Act); a beneficiary of an instruction concerning a deposit in the event of death (art 56(1) of the Banking Act), provided that their claim towards the bank had become due before the date on which the guarantee condition was fulfilled. The following types of deposit are excluded from the coverage of the BFG: State Treasury; financial institutions sensu largo in the meaning of the EU law, such as credit institutions, ${ }^{12}$ insurance institutions ${ }^{13}$ and investment institutions $;{ }^{14}$ members of the board of directors and management of the

obligation beyond the minimum stipulated in the obligatory funds guarantee system (art 39(1) of the Act on the BFG).

10 When a bank branch which sets up business in another EU member state where the coverage level is higher or the scope broader than in its home country has the right to join the host country DGS, this is known as a 'topping-up' arrangement.

${ }^{11}$ Journal of Laws 2002 No. 72, item 665 (as amended) (The Banking Act).

12 Domestic banks, foreign banks and credit institutions, but also cooperative savings and credit funds, and the National Cooperative Savings and Credit Union.

${ }^{13}$ National and foreign insurance institutions, national and foreign insurance companies, as well as the Insurance Guarantee Fund.

${ }^{14}$ Companies operating exchanges, out of exchange markets or alternative trading systems, investment companies, foreign investment companies and foreign legal persons conducting 
bank, as well as other people occupying managerial positions in the bank and shareholders of at least five per cent of the capital of the credit institution. $^{15}$

The Fund guarantees deposits, i.e. funds deposited with a bank by the depositor in accounts held in the name of the depositor and claims of a depositor resulting from other bank operations in PLN or foreign currencies as at the date of fulfillment of the guarantee condition, confirmed by documents issued by this bank in the name of the depositor or registered depository certificates (art 2(2) of the Act on the BFG). Where one account is held for several persons (a joint account, e.g. of a married couple), each of these persons shall be a depositor, within the limits stipulated in the account agreement, and in the absence of contractual arrangements or relevant provisions in equal parts. ${ }^{16}$

\section{Polish IMPLEMENTATION Details}

Directive 2009/14/EC was implemented in three acts: the Act amending the Act on the BFG and a number of other acts of 23 October $2008,{ }^{17}$ the Act amending the Act on the BFG and the Banking Act of 16 July $2009^{18}$ and the Act amending the Act on the BFG and a number of other acts of 16 December $2010 .{ }^{19}$

When the crisis on the financial market deepened in autumn 2008 the guaranteed amount in Poland was at the level of EUR 22,500. If the amount of deposits did not exeeded the equivalent of EUR 1,000, the deposit was $100 \%$ guaranteed. Amounts of between EUR 1,000 and EUR 22,500 were $90 \%$ guaranteed. The assets above the upper limit of the guarantee could be claimed from bankruptcy assets. From 13 December 2008 (the date on which the Amendment of the Act on the BFG of 2008 came into force) the limit of the guarantee was increased to the equivalent of EUR 50,000 in order to maintain depositor confidence and attain greater stability on the financial markets. It was a result of the conclusion of the Economic and Financial Affairs Council (ECOFIN) of 7 October $2008^{20}$ recommending all Member States provide deposit guarantee protection for individuals for an amount of at least EUR 50,000, and raise this minimum to EUR 100,000 if possible. The guarantee limit in the Act on the BFG was changed before 11

\footnotetext{
brokerage activity, as well as the National Depository for Securities; national investment funds and management companies; investment funds, investment fund companies, foreign funds, management companies and branches of investment companies, as well as open pension funds, employee pension funds, general pension societies and employee pension societies.

${ }^{15}$ As well as persons being in relations with them.

16 The maximum level of compensation is EUR 100,000 per firm also in the case of an account for a civil law, registered, general, limited or limited joint-stock partnership (art $2 \mathrm{a}(2)$ the Act on the BFG).

17 Journal of Laws No. 209 item 1315 (The Amendment of the Act on the BFG of 2008).

18 Journal of Laws No. 144 item 1776 (The Amendment of the Act on the BFG of 2009).

${ }^{19}$ Journal of Laws No. 257 item 1724 (The Amendment of the Act on the BFG of 2010).

20 Ecofin Council, Immediate responses to financial turmoil (Conclusions 2008) 13930/08.
} 
March 2009 which was the date on which Directive 2009/14 was published. ${ }^{21}$

The Amendment of the Act on the BFG of 2010 suppressed the principle which means that the full amount of funds collected by a customer will be paid out, up to the guarantee limit, without reduction by the amount of loans taken in a given bank.

The second of the most important changes in the Act on the BFG was a shortening of the length of payout to 20 days from 30 December 2010. The previous three-month term, which could be lengthened to as much as nine months was perceived as too long, considering that nowadays people barely retain cash at home and thus the term should be as short as possible. Otherwise people would not be able to spend money on their everyday needs. $^{22}$ In the opinion of the Commission even this shortened payout period is still too long and needs to be reduced to seven days (by the end of 2013), and even to three days following a transitional period.

The entities covered by the guarantee system are obliged to establish a fund for protection of guaranteed assets to satisfy depositor claims in the case of fulfillment of guarantee conditions by any entity covered by this system (the so-called 'sleeping fund'). The inability of a credit institution to repay its deposits is determined by the Polish Financial Supervision Authority. Where such a situation arises, the FSA issues a formal decision (art 2(4)(a) of the Act on the BFG). This means that the decision of a court on declaration of bankruptcy is unnecessary for the BFG to begin a payout of the guarantee.

In the case of a domestic bank the fund for protection of guaranteed assets is activated by the FSA issuing a decision on the suspension of the activity of a bank and appointment of a trustee administrator there, before a bankruptcy petition has been lodged with a relevant court. In case of a branch of a credit institution a foreign court or a supervisory authority of the home country of the credit institution concerned will issue a provision or decision which deprives or limits the entity covered by the guarantee system within the law of management of the assets of the entity, or submit the entity to inspection with the objective of its reorganisation or liquidation in the course of bankruptcy proceedings in the native state. In the event of fulfillment of the guarantee condition, a trustee administrator of the domestic bank, a foreign manager or another authority authorized for representation should immediately transfer to the BFG the money from the fund for protection of guaranteed assets.

The object of the guarantee is the claim of a depositor, whereby the depositor acquires, on the day of fulfillment of the guarantee condition, the

${ }^{21}$ It is worth emphasizing that 11 years after implementation into national law, before publication of Directive 2009/14/EC, the Commission had been reviewing Directive 94/19/EC in order to assess whether the existing rules were still fit for purpose in light of the continuing trend towards financial integration and cross-border mergers between credit institutions. In particular, the differences between the way schemes are financed have been cited in the consultations of the Commission by some as posing an obstacle to cross-border consolidation and as unfair from a competition perspective. See Commission 'The review of Directive 94/19/EC on Deposit Guarantee Schemes' (Communication) COM (2006) 729 final, ch I.

22 See Dave Skelsey, 'Consumer awareness of the Financial Services Compensation Scheme’ (2009) 75 Financial Services Authority Research Paper 3. 
right to receive financial means from the Fund. The pecuniary means should be payable in PLN, within 20 working days of the day of this fulfillment. In particular, owing to inaccuracies in the keeping of books of account at the bank or in the functioning of the calculation system of the entity covered by the guarantee system, the Polish Financial Supervision Authority may, at the request of the Fund Management Board, postpone the disbursement date, although not by more than 10 working days (art 22(4) of the Act on the BFG).

In a situation in which the guarantee condition is fulfilled, a trustee administrator of a domestic bank, a foreign manager or another authority authorized for representation should immediately transfer the funds to the Fund from the fund for protection of guaranteed assets (art 26a(1) of the Act on the BFG). The Fund shall notify the entities covered by the obligatory guarantee system of the obligation of compensating the Fund with payments allocated for disbursement of guaranteed assets. The assets from mandatory payments of entities covered by the guarantee system shall be transferred to the ownership of the Fund (art 26a of the Act on the BFG).

The trustee administrator of the bank or the entity entitled to represent are responsible for drawing up a list of depositors and should submit the depositor list to the Fund not later than within three working days of the day on which fulfilment of the guarantee condition occurs. The Fund Management Board shall exercise current control over the drafting of the list of depositors by the trustee administrator or the entity entitled to represent. The trustee administrator, the entity entitled to represent or the entity with whom the Fund shall conclude an agreement on disbursement of guaranteed funds, shall disburse the guaranteed funds on behalf of and on account of the Fund. Depositor claims on account of the guarantee undisclosed in the list of depositors shall be satisfied by the Fund within 20 working days of the day of receipt of a completed list of depositors by the manager or the bankruptcy trustee or a fixed list of receivables or receivables against the entity covered by the obligatory guarantee system, against whom the guarantee condition was fulfilled, confirmed by a final court judgement (art $26 \mathrm{p}$ (1) the Act on the BFG).

The Fund should make payouts on its own initiative (without being prompted by applications from depositors) and confirmation of claims should be simplified. The guaranteed assets are payable on the basis of data included in the calculation system of the entity covered by the guarantee system (art 38d of Act on the BFG). The amendment to the Act on the BFG of 2010 imposed the legal duty that banks should implement and maintain a properly functioning calculation system. The data allowing identification of the depositors, their place of residence or their headquarters and determination the amount of guaranteed funds that are due to individual depositors should be drawn up daily in the calculation system, as at the close of the day. Such a system is called a 'single customer view'. This system cannot be beyond the territory of Poland and should ensure renewal of data and access to data for the Polish Financial Supervision Authority as well as the Fund.

It should be emphasized that the remainder of the guarantee rules which are key to depositors - were preserved in the Amendment to the Act on the BFG of 2010. Irrespective of currency, deposits in PLN, as well as in 
foreign currencies, are equally protected and paid out in PLN. In the case of joint accounts, each joint account co-owner is entitled to a separate guaranteed amount up to the guarantee limit. The guaranteed funds can be collected by a depositor within five years of the day on which suspension of the operations of a bank occurs.

It is worth considering that local authorities and persons responsible for auditing the accounting documents of the bank, as well as persons of similar status in the other companies having direct or indirect control over the bank, are not excluded from the definition of 'depositor'. Since 30 December 2010 the Fund has guaranteed the deposits of small and mediumsized enterprises (SMEs). Before 30 December 2010 enterprises were differentiated because SMEs were not permitted to draw up abridged balance sheets and profit and loss accounts were not protected.

\section{FUTURE OUTLOOK FOR EU REGULATION}

It is worth emphasizing that in the EU there are varying DGS funding mechanisms, these usually funded by contributions from credit institutions themselves, on an ex-ante, ex-post or mixed basis. Consultation between member countries has shown that a clear majority does not wish to harmonize financing mechanisms at this moment, since they believe that the costs entailed would be greater than the expected benefits. Substantial differences exist in the manner by which schemes fund payouts to depositors. The ex-post funded schemes rely on collection of the funds from members of the scheme once a bank has failed, while ex-ante funded schemes collect funds from members of the scheme through the levying of contributions; there are also significant differences between the size of $e x$ ante funded schemes. ${ }^{23}$ Such differences, it is claimed, raise doubts about the ability of schemes to function on a cross-border basis under crisis conditions, create competitive distortions because of the unfair advantage to banks operating under schemes with lower costs, and are cited as an obstacle for a bank seeking to consolidate its operations using the European Company Statute. ${ }^{24}$

It is often argued that mere ex-post funding is highly pro-cyclical as it drains liquidity from banks in times of stress. It might worsen the overall situation of sound banks and has implications for credit supply by banks. ${ }^{25}$ Ex-post systems (still in existence in six Member States) have more serious drawbacks. In normal times, banks that do not pay ex-ante contributions have a competitive advantage vis-à-vis banks in Member States with an ex-

${ }^{23}$ Commission, 'Review of Directive 94/19/EC on Deposit Guarantee Schemes' (Report) COM (2010) 369 final, 3.

24 ibid 3.

25 Elemér Terták and Konrad Szeląg, 'The Financial Crisis and the Reform of Deposit Guarantee Schemes in the EU' (2010) 2 Bezpieczny Bank/Safe Bank 106; See also: European Commission, 'Consultation on the review of the Directive on Deposit Guarantee Schemes' (May-July 2009)

$<$ http://ec.europa.eu/internal_market/consultations/docs/2009/deposit_guarantee schemes/c onsultation_dgs 2009 en.pdf $>$ accessed 30 March 2011. 
ante DGS. In ex-post systems, unlike in ex-ante ones, the failed bank does not contribute to payout (which increases moral hazard). ${ }^{26}$

Although a DGS is designed to deal with and minimise systemic risk, it can actually have negative effects too. This is because the safety net offered by such schemes may encourage banks to assume excessive risks which could take the form of excessive lending to borrowers who are not creditworthy or, more generally, a tendency toward imprudent management of the money of their depositors. ${ }^{27}$ This is known as the 'moral hazard' problem. Depositors, in turn, reassured by the existence of the guarantee schemes, may neglect to check the solvency of the credit institutions where they place their deposits, which can lead to misallocation and misuse of resources and may have a dampening effect on the role of the market and market discipline in the banking system. ${ }^{28}$

Some deposit guarantee schemes already base contributions to their scheme on the individual risk of credit institutions, in line with the recommendation of the G10 Financial Stability Forum. ${ }^{29}$ The Commission supports the introduction of risk-based elements and recommends that the determination of risk should be based on tools already available and harmonized (e.g. those within the Capital Requirements Directive framework).$^{30}$ Regarding bank contributions to a DGS, these are set in most Member States as a fixed percentage of deposits (usually eligible deposits). Under such a system, the degree of risk incurred by a given bank is not taken into account. This may be perceived by risk-averse banks as a competitive disadvantage and a disincentive for sound risk management. ${ }^{31}$

The consultation process has also revealed that certain stakeholders would be in favour of introducing a de minimis clause into the Directive, whereby very small deposits would not be reimbursed, in that the administrative costs would exceed the amount of the reimbursement. There would seem to be very little impact on cross-border activities since it is unlikely that the amounts in question (e.g. EUR 20, the amount suggested by the Commission services in the consultation paper) would be decisive for depositors. On the other hand, modern IT systems should help to minimise administrative costs. ${ }^{32}$

26 ibid.

27 Hellenic Deposit Guarantee Fund, '2009 Report' <http://www.hdgf.gr/docs/EV.pdf> accessed 30 March 2011.

28 ibid.

$29<$ http://www.fsforum.org/publications/Guidance_deposit01.pdf $>$ accessed 30 March 2011.

${ }^{30}$ Directive 2006/48/EC relating to the taking up and pursuit of the business of credit institutions [2006] OJ L177/1; Directive 2006/49/EC on the capital adequacy of investment firms and credit institutions [2006] OJ L177/201. See also: European Commission, Investigating the Efficiency of EU Deposit Guarantee Schemes (Report May 2008)

$<$ http://ec.europa.eu/internal_market/bank/docs/guarantee/deposit/report_en.pdf $>$ accessed 30 March 2011; European Commission, Risk-based contributions in EU Deposit Guarantee Schemes: current practices (Report June 2008) $\leq$ http://ec.europa.eu/internal_market/bank/docs/guarantee/risk-based-report_en.pdf $>$

accessed 30 March 2011; European Commission, Possible models for risk-based contributions to EU Deposit Guarantee Schemes (Report June 2009) $<$ http://ec.europa.eu/internal market/bank/docs/guarantee/2009 06 risk-basedreport en.pdf $>$ accessed 30 March 2011.

${ }^{31}$ Terták and Szeląg (n 25) 108.

32 Report (n 23) 3. 


\section{CONCLUSION}

All over the world a DGS is designed to reduce the likelihood of an extensive withdrawal of deposits under conditions of panic by providing guarantees for the protection of depositors. When the bank system operates normally, depositors have a sense of security and predictability that minimizes the risk of a depositor confidence crisis. The failure of just one credit institution to meet its obligations toward its depositors may be sufficient to disturb the smooth functioning and stability of the credit system of a country as a whole. Guarantees are needed by savers, in particular small savers, given their limited access to information that would enable them to assess properly the solvency of the credit institution with which they have entrusted their savings. This calls for the establishment of a minimum level of coverage by the deposit guarantee scheme so as to address the situation that arises when one or more credit institutions fail to return deposits. The EU legislator is making an effort to bring the various deposit guarantee schemes currently operative in the EU into line with one another.

It is worth noting that 2009 and 2010 were years of important legislative changes in the Act on the BFG. The most significant challenges are shortening the time required for disbursement of guaranteed sums to 20 days and the proposed increase of these amounts to EUR 100,000. Among the most important challenges faced by deposit guarantee systems, also deserving of a special mention is the beginning of the payout process on the day of the suspension of bank operations by the FSA and filing of the petition for declaration of bank bankruptcy. A significant change was also the covering of all enterprises by guarantee deposits (excluding financial institutions, which were indicated directly in the Act on the BFG). At this moment the Act on the BFG generally corresponds to the EU Directives. 